\title{
Tumor Necrosis Factor- $\alpha$ Eliminates Binding of NF-Y and an Octamer-binding Protein to the Lipoprotein Lipase Promoter in 3T3-L1 Adipocytes
}

\author{
Catherine L. Morin, Isabel R. Schlaepfer, and Robert H. Eckel \\ Department of Endocrinology, Metabolism, and Diabetes, University of Colorado Health Sciences Center, Denver, Colorado 80262
}

\begin{abstract}
TNFa has been shown to reduce lipoprotein lipase (LPL) activity in adipose tissue. Regulation of LPL by TNFa occurs at the level of LPL gene transcription and posttranscriptionally. To elucidate further the transcriptional mechanism of TNF $\alpha$ inhibition of LPL gene transcription, transfection analysis was used to locate the site(s) of the LPL promoter that imparts the TNF $\alpha$ response. Transient transfections using LPL promoter deletions fused to luciferase in differentiated 3T3-L1 cells with and without TNF $\alpha$ treatment indicated that a DNA region downstream of -180 bp confers the TNF $\alpha$ effect. Electrophoretic mobility shift assays using two ${ }^{32} \mathbf{P}$-labeled LPL probes spanning the region between -180 and +44 bp revealed the loss of several LPL DNA-protein interactions after TNF $\alpha$ treatment, including the binding of NF-Y to the CCAAT box and a protein to the octamer consensus sequence. Protein binding to the OCT-1 consensus sequence is unaffected until after $4 \mathrm{~h}$ of TNFa treatment. In addition, the amount of mRNA for OCT-1 is not altered with TNF $\alpha$ treatment. These results indicate that TNF $\alpha$ regulates at least two DNA-binding proteins on the proximal promoter, thereby inhibiting LPL gene transcription. (J. Clin. Invest. 1995. 95:1684-1689.) Key words: lipoprotein lipase - tumor necrosis factor - octamer binding protein $\cdot$ NF-Y $\cdot 3 T 3-L 1$ cell
\end{abstract}

\section{Introduction}

TNF $\alpha$ has recently been shown to be synthesized by and secreted from adipose tissue, adding adipose tissue to the evolving list of nonimmune tissues that produce cytokines (1). TNF $\alpha$ was determined to be identical to cachectin, which was first discovered because it decreased adipose tissue lipoprotein lipase (LPL) ${ }^{1}$ activity $(2,3)$. LPL, a key enzyme in lipid metabolism, is responsible for the hydrolysis of triglycerides from circulating triglyceride-rich lipoproteins, providing free fatty acids and monoacylglycerol for cellular uptake. This decrease in adipose tissue LPL is dose dependent and associated with reductions in steady-state LPL mRNA and transcription of the LPL gene (3).

Address correspondence to Dr. Catherine Morin, UCHSC B151, 4200 East 9th Street, Denver, CO 80262. Phone: 303-270-8447; FAX: 303270-4525.

Received for publication 21 October 1994 and in revised form 12 December 1994.

1. Abbreviations used in this paper: EMSA, electrophoretic mobility shift assay; LPL, lipoprotein lipase.

J. Clin. Invest.

(C) The American Society for Clinical Investigation, Inc.

0021-9738/95/04/1684/06 \$2.00

Volume 95, April 1995, 1684-1689
TNF $\alpha$ has been implicated as a contributor to the wasting syndrome noted in some cancers and in acquired immunodeficiency syndrome $(4,5)$. However, elevated production of TNF $\alpha$ in adipose tissue has also been seen in many models of insulin resistance and obesity, including the $f a / f a, o b / o b$, and $d b / d b$ rodents (1). Because the expression of adipose tissue LPL is altered in both cachexia (6) and obesity (7), elucidation of its regulation by TNF $\alpha$ may provide additional insights into the molecular mechanisms by which TNF regulates adipose tissue metabolism and perhaps systemic fuel balance.

To characterize the effect of TNF $\alpha$ on LPL gene transcription, two experimental strategies were used. First, transfections of LPL promoter-luciferase reporter gene constructs were used to locate the region(s) of the LPL gene that confers the TNF $\alpha$ response. Second, electrophoretic mobility shift analysis (EMSA) was performed to identify both the TNF $\alpha$-dependent changes in nuclear protein-LPL DNA interactions and the proteins involved. Results indicate that TNF $\alpha$ inhibits LPL gene transcription at least in part through the loss of the DNA interactions of NF-Y and an octamer-binding protein in the proximal promoter, regions largely responsible for basal LPL gene transcription.

\section{Methods}

Materials. Recombinant human TNF $\alpha$ was obtained from Mallinckrodt (Paris, KY) and murine TNF $\alpha$ was from R \& D Systems (Minneapolis, MN). Glycerol tri $\left[1-{ }^{14} \mathrm{C}\right]$ oleate $(57 \mathrm{mCi} / \mathrm{mmol})$ and $\left[1-{ }^{14} \mathrm{C}\right]$ oleic acid $(53 \mathrm{mCi} / \mathrm{mmol}$ ) were obtained from Amersham Corp. (Arlington Heights, IL). $\left[{ }^{32} \mathrm{P}\right]$ ATP and $\left[{ }^{32} \mathrm{P}\right] \mathrm{CTP}(3,000 \mathrm{Ci} / \mathrm{mmol})$ were from New England Nuclear Research Products (Boston, MA). HeLa cell nuclear extract and anti-OCT-1 antibodies were purchased from Santa Cruz Biotechnology; Inc. (Santa Cruz, CA). PCR reagents were purchased from Perkin-Elmer Cetus Corp. (Norwalk, CT).

Tissue culture. 3T3-L1 cells, kindly provided by Dr. M. Daniel Lane (Johns Hopkins University School of Medicine), were grown in DMEM (prepared by a University of Colorado Cancer Center Tissue Culture Core laboratory), high glucose ( $4.5 \mathrm{~g} /$ liter), supplemented with $10 \%$ FBS (Hyclone, Logan, UT), $1 \mathrm{mM}$ sodium pyruvate, $4 \mathrm{mM} \mathrm{L-glutamine,}$ and $0.1 \mathrm{mM}$ nonessential amino acids (all from Gibco BRL, Grand Island, NY). Cells were grown at $37^{\circ} \mathrm{C}$ in a humidified atmosphere of $5 \% \mathrm{CO}_{2}$. Differentiation was induced by treating confluent cells with insulin $(10 \mu \mathrm{g} / \mathrm{ml})$, dexamethasone $(390 \mathrm{ng} / \mathrm{ml})$, and isobutyl methylxanthine $(115 \mu \mathrm{g} / \mathrm{ml})$ for $48 \mathrm{~h}(8)$. Cells were fed every $2-3 \mathrm{~d}$ thereafter with medium supplemented with insulin alone. Cells were used for experiments on the eighth day after the start of differentiation, $1 \mathrm{~d}$ after the last feeding.

Transfections. Constructs, containing murine LPL promoter fragments in a p19Luc vector, generously provided by Dr. J. M. Gimble (Oklahoma Medical Research Foundation), were transfected on the third day after the start of differentiation by electroporation (Gene Pulser with Capacitance Extender, Bio-Rad, Richmond, CA) at $250 \mu \mathrm{F}, 250$ $\mathrm{mV}$, infinite resistance, in 0.4-cm cuvettes. Cells were replated in complete medium with insulin, and TNF $\alpha$ was added immediately to the treated cells. All dishes were cotransfected with an SV40 $\beta$-galactosidase plasmid to monitor transfection efficiency. Transfection experiments included negative (mock) and positive (Rous sarcoma virus- 
luciferase plasmid) controls. Dishes were harvested $24 \mathrm{~h}$ later, and $\beta$ galactosidase activity was measured (9). Aliquots of cellular extract were frozen for luciferase determinations using D-luciferin as a substrate (Monolight 2010 Luminometer; Analytical Luminescence Laboratory, San Diego, CA).

Reverse transcriptase PCR. RNA was isolated from differentiated 3T3-L1 cells (10). RNA aliquots, previously treated with DNase I, were denatured at $75^{\circ} \mathrm{C}$ for $5 \mathrm{~min}$, chilled on ice, and added to PCR buffer containing $50 \mathrm{mM} \mathrm{KCl}, 10 \mathrm{mM}$ Tris- $\mathrm{HCl}, \mathrm{pH} 8.3,1 \mathrm{mM}$ deoxynucleotide triphosphates, $5 \mathrm{mM} \mathrm{MgCl}, 1 \mathrm{U} / \mu \mathrm{l}$ RNase inhibitor, $25 \mathrm{pmol}$ of random hexamers, and $2.5 \mathrm{U} / \mu \mathrm{l}$ murine leukemia virus reverse transcriptase (RT) to a final volume of $20 \mu \mathrm{l}$. For every RNA sample, an identical reaction was performed with no RT to ensure the DNase treatment was successful. All no-RT reactions were negative, indicating that all PCR products were of RNA origin. Samples were incubated at $37^{\circ} \mathrm{C}$ for $1 \mathrm{~h} .80 \mu \mathrm{l}$ of PCR buffer containing 25 pmol of each primer (see below), $2 \mathrm{mM} \mathrm{MgCl}$, and $2.5 \mathrm{U} / 100 \mu 1$ Taq polymerase was then added. 25 cycles of PCR (Perkin-Elmer Cetus Corp.) were performed in the following manner: $1 \min 94^{\circ} \mathrm{C}, 1 \min 58^{\circ} \mathrm{C}, 10 \mathrm{~s} 72^{\circ} \mathrm{C} .25$ cycles were previously identified as being in the linear range for PCR amplification of both OCT-1 and $\beta$-actin using $1 \mu \mathrm{g}$ of RNA from differentiated 3T3-L1 cells. The following primers used were:

\section{OCT-1: 5'-GCAATCAAGGTGATGTCTTCC-3'}

\section{5'-AGCCTTGAACCTCAGCTTTAAG-3'}

\section{$\beta$-actin: 5'-GTGGGCCGCTCTAGGCACCAA-3'}

\section{5'-CTCTTTGATGTCACGCACGATTTC-3'}

The OCT-1 primers were synthesized at DNA International (Lake Oswego, OR), and the $\beta$-actin primers were purchased from Clontech (Palo Alto, CA).

LPL assay. Heparin-releasable LPL activity was measured as described previously (11). Briefly, 3T3-L1 cells were incubated in a heparin-containing Krebs Ringer phosphate buffer and assayed with an emulsified $\left[{ }^{14} \mathrm{C}\right]$ triolein substrate.

EMSA. 3T3-L1 nuclear extracts were prepared according to the method of Dignam et al. (12), and protein concentrations were determined using the BCA Protein Assay (Pierce, Rockford, IL). Both the 120-bp ( 180 to $-60 \mathrm{bp})$ and the 103-bp ( -59 to +44$)$ DNA fragments used as probes were obtained from restriction enzyme digestion of murine proximal LPL promoter and gel purified using a Qiaex gel extraction kit (Qiagen, Chatsworth, CA). The NFkB probe was made by hybridizing two oligonucleotides synthesized at the University of Colorado Cancer Center Oligonucleotide Core Facility: 5'-ATCTGTGGAAAGTCCCA-3' and 5'-AGTGGGACTTTCCACAG-3'. OCT-1 and NF-Y probes, based on the murine LPL sequence (13), were prepared from oligomers synthesized at DNA International:

\section{OCT-1: 5'-TCGACGATGAGTCTTA}

\section{TTTGCATATTTCCAGTCAG-3}

\section{5'-TCGACTGACTGGAAAT}

\section{ATGCAAATAAGACTCATCG-3'}

\section{NF-Y: 5'-TCGACAACCTCATCAC \\ CTATTGGCTATAAAATCATAAGG-3' \\ 5'-TCGACCTTATGATTTTA \\ TAGCCAATAGGTGATGAGGTTG-3'}

All oligomers were then annealed by combining equal molar amounts of each oligomer in Tris-EDTA buffer ( $10 \mathrm{mM}$ Tris, $1 \mathrm{mM}$ EDTA),

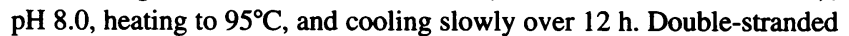
oligonucleotides were radiolabeled using Klenow fragment from DNA polymerase I, $\left[\alpha-{ }^{32} \mathrm{P}\right] \mathrm{dATP}$, and $\left[\alpha-{ }^{32} \mathrm{P}\right] \mathrm{dCTP}$. Probes were purified by Sephadex G50 columns (Sigma Chemical Co., St. Louis, MO). Radiolabeled DNA probes $(20,000 \mathrm{cpm})$ were incubated with nuclear

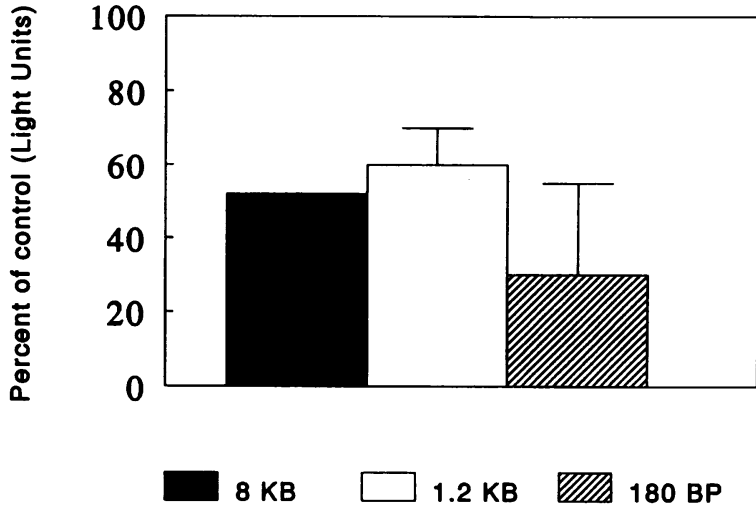

Figure 1. Effect of TNF $\alpha$ on LPL promoter constructs (mean of two experiments). Plasmids containing LPL promoter constructs, fused to luciferase, were transfected by electroporation into 3T3-L1 cells on day 3 after the initiation of differentiation. $10 \mathrm{ng} / \mathrm{ml}$ TNF $\alpha$ was added to the treatment dishes when cells were replated. Cells were harvested 24 $\mathrm{h}$ later. The largest fragment contained $7.8 \mathrm{~kb}$ upstream of +188 ( 8 $\mathrm{kb})$. The second fragment was -1254 to $+188 \mathrm{bp}(1.2 \mathrm{~kb})$, and the third fragment was located -180 to $+188(180 \mathrm{bp})$. Results are expressed as the percentage of control dishes and are corrected for $\beta$ galactosidase activity to control for transfection efficiency.

extracts (2-8 $\mu \mathrm{g}$ of protein) previously combined with nonspecific and/ or specific DNA competitors. Binding reactions were performed in 10 $\mathrm{mM}$ Tris, $\mathrm{pH} 8.0,50 \mathrm{mM} \mathrm{NaCl}, 1 \mathrm{mM}$ DTT, $1 \mathrm{mM}$ EDTA, $10 \%$ glycerol, $10 \%$ poly $(\mathrm{dI}-\mathrm{dC})$ for $30 \mathrm{~min}$ at $25^{\circ} \mathrm{C}$. The samples were run on a $3 \%$ polyacrylamide gel (60:1 acrylamide/bisacrylamide ratio) containing $25 \mathrm{mM}$ Tris $-25 \mathrm{mM}$ boric acid- $0.5 \mathrm{mM}$ EDTA. EMSA supershifts were performed by incubating the appropriate antibody with prebound probe-protein complexes for an additional $20 \mathrm{~min}$ at $30^{\circ} \mathrm{C}$. Gels were electrophoresed at $140 \mathrm{~V}$ for $\sim 1.5 \mathrm{~h}$ at room temperature. Dried gels were exposed to XAR-5 film (Eastman Kodak Co., Rochester, NY) overnight with an intensifying screen at $-70^{\circ} \mathrm{C}$.

\section{Results}

Preliminary experiments indicated that $10 \mathrm{ng} / \mathrm{ml} \mathrm{TNF} \alpha$ would maximally suppress ( $>95 \%$ ) heparin-releasable LPL activity in differentiated 3T3-L1 cells. Additionally, LPL mRNA was measured by Northern blot to confirm previous findings. On average (mean of two experiments), a decrease of $64 \%$ in LPL mRNA was observed in differentiated 3T3-L1 cells treated with TNF $\alpha$ for $18 \mathrm{~h}$ (data not shown). This concurs with the results of Zechner et al. (3) and Cornelius et al. (14), who reported 75 and $60 \%$ reductions in LPL mRNA, respectively.

Transfection analysis was performed with three LPL promoter fragments, each fused to a luciferase reporter construct. The largest fragment contained $7.8 \mathrm{~kb}$ of $5^{\prime}$ to $+188(8 \mathrm{~kb})$. The second fragment was -1254 to $+188 \mathrm{bp}(1.2 \mathrm{~kb})$, and the third fragment was -180 to +188 (180 bp). TNF $\alpha$ treatment after transfection resulted in a reduction to 48,60 , and $33 \%$ of control luciferase activity for the $8 \mathrm{~kb}, 1.2 \mathrm{~kb}$, and $180 \mathrm{bp}$ promoter fragments, respectively (Fig. 1). This reduction in luciferase activity was also seen when murine TNF $\alpha$ was used as the treatment in transfected cells (data not shown). Because the smallest LPL promoter fragment ( $180 \mathrm{bp}$ ) included the LPL promoter region(s) necessary for TNF $\alpha$ inhibition, efforts were concentrated on this portion of LPL DNA.

Using convenient restriction enzyme sites in the 180 -bp fragment, two sequential probes were produced and purified for 
Hind III

$\checkmark$ caaggetttccttcctgccotttccccttcttctcgctggcaccgttgagcctcgttaccg $\frac{180}{-180}$ 120 PROBE

tttgctcaaatatttggaagtgcatttagagtcctcccccaacttatgattttatagCC $\frac{\text { AATaggtgatgagtcttATTTGCATattccagtcacTTAAAcagctgtgcagt }}{103 \text { PROBE }}$

Figure 2. Nucleotide sequence of the murine LPL promoter from -180 to +44 bp with partial restriction enzyme map. DNA fragments used as electrophoretic mobility shift analysis probes are denoted as 120 $P R O B E$ and $103 P R O B E$. Uppercase letters indicate important regulatory consensus sequences.

use in the EMSA (Fig. 2). The first probe was $120 \mathrm{bp}$ and comprised the -180 to -60 fragment of the LPL promoter, which contains the consensus sequence for the CCAAT box. The second probe was $103 \mathrm{bp}$ in length, from -59 to +44 , and contained the consensus sequences for OCT-1, a nonconsensus TATA box, and a TRE consensus sequence previously identified (15).

The more proximal 103-bp probe, which contains the consensus sequences for OCT-1 and the nonconsensus sequence for the TATA box, showed two bands in the control extract, whereas cells treated with TNF $\alpha$ did not have either of these bands (Fig. 3). Cold competition with $50 \times$ unlabeled 103bp probe substantially reduced the amount of protein-DNA interaction in the control extracts, suggesting that the proteinLPL promoter interaction was specific for this piece of DNA (Fig. $4 \mathrm{~A}$ ). This specificity was further confirmed by competition with an unrelated DNA fragment that failed to reduce the magnitude of the protein-LPL promoter interaction (Fig. $4 \mathrm{~B}$ ).

The 120-bp probe used in the EMSA, located farther upstream and containing the consensus sequence for the CCAAT box, also revealed two bands in the control extract (Fig. 3). Both of these bands were absent in the binding reactions using the TNF $\alpha$-treated nuclear extracts. As with the 103-bp probe,

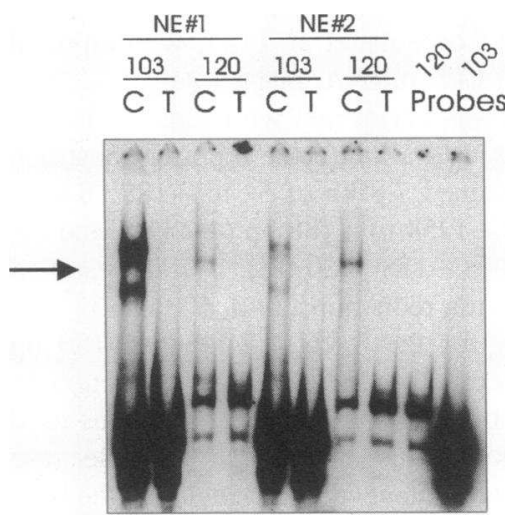

Figure 3. Electrophoretic mobility shift analysis of the proximal murine LPL promoter. Nuclear extracts (NE\#1 and NE\#2) were prepared (12) from differentiated 3T3-L1 cells previously treated with $(T)$ or without $(C)$ $10 \mathrm{ng} / \mathrm{ml}$ TNF $\alpha$. The arrow indicates the bands of interest. The 103-bp probe $(-59$ to +44$)$ and the 120 -bp probe $(-180$ to -60 ) were gel purified and radiolabeled with

$\left[\alpha-{ }^{32} \mathrm{P}\right] \mathrm{dATP}$ and $\left[\alpha-{ }^{32} \mathrm{P}\right] \mathrm{dCTP}$. 30-min binding reactions were run on a $3 \%(60: 1)$ polyacrylamide gel for $1.5 \mathrm{~h}$ at $130 \mathrm{~V}$. Gels were dried and exposed to film.
A

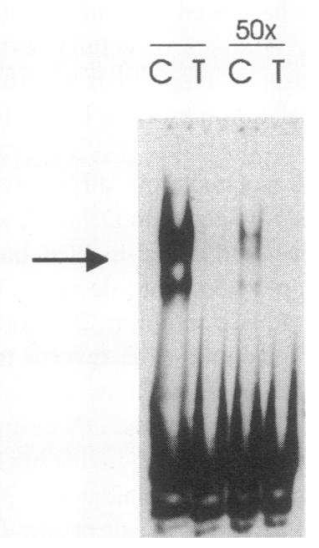

B

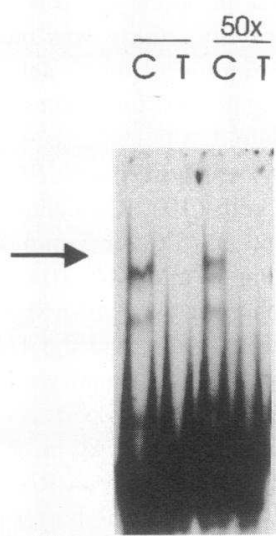

Figure 4. EMSA of the 103-bp probe. (A) Binding proteins for the 103bp probe were competed away with a $50 \mathrm{M}$ excess of unlabeled probe by preincubation of the nuclear extract from cells with $(T)$ or without (C) TNF $\alpha$ with the unlabeled 103-bp probe for $10 \mathrm{~min}$ before the addition of the radiolabeled probe. $(B)$ Competition of the 103-bp probe with an unrelated $300-\mathrm{bp}$ fragment of the LPL promoter $(-1550$ to $-1250 \mathrm{bp}$ ).

$50 \times$ cold competition with unlabeled 120 -bp probe reduced the degree of protein-LPL promoter interaction (data not shown).

Because the TNF $\alpha$-treated nuclear extracts showed an absence of transcription factors with two LPL probes, the possibility that the extracts were devoid of transcription factors needed to be eliminated. An NF $\kappa$ B oligo was chosen to confirm the presence of operational transcription factors because in many cell types such as HeLa or human myeloid cells $(16,17), \mathrm{NF} \kappa \mathrm{B}$ is increased with TNF $\alpha$ treatment (Fig. 5). This proved to be true in differentiated 3T3-L1 cells also.

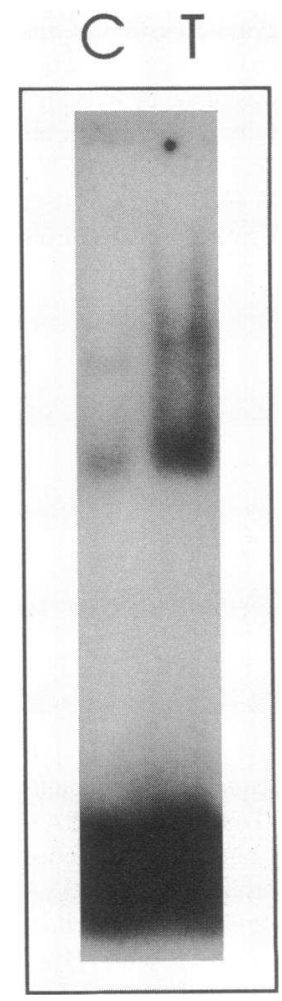

Figure 5. EMSA to confirm the presence of operative transcription factors. A radiolabeled $\mathrm{NF} \kappa \mathrm{B}$ oligonucleotide probe was used to test all nuclear extracts. $T$, treated with TNF $\alpha ; C$, without TNF $\alpha$. This autoradiogram is representative of all the extracts examined. 


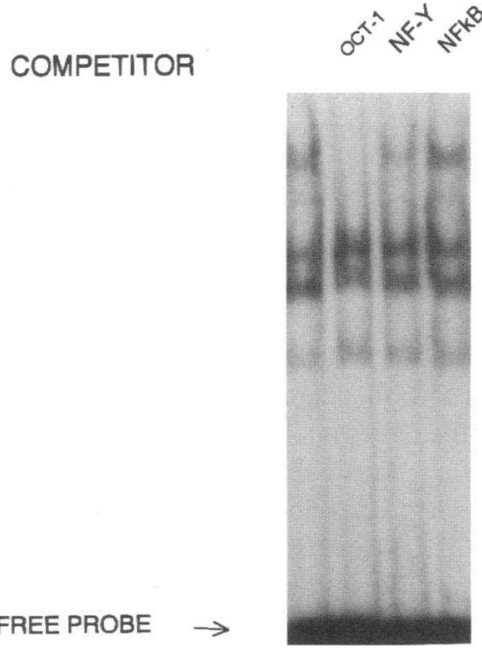

B

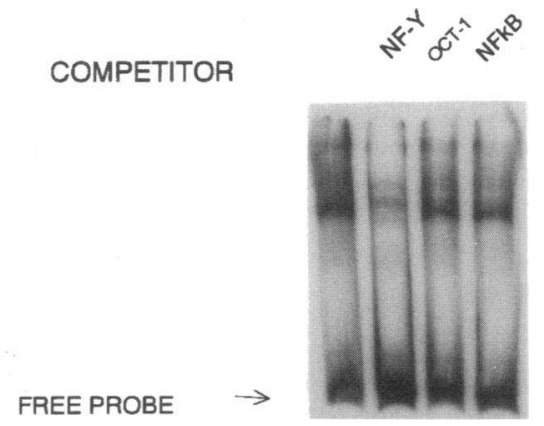

Figure 6. EMSA with unlabeled double-stranded transcription factor consensus sequence oligonucleotides. $(A)$ Competition analysis using the 103-bp probe, which contains the octamer-binding sequence. Competition analysis was performed by preincubation of nuclear extract with a 40-fold excess of one of three unlabeled consensus sequences (OCT1, NF-Y, or NFkB). (B) Competition analysis using the 120-bp probe, which contains the NF-Y-binding CCAAT box and unlabeled consensus sequence oligonucleotides.

Consensus sequences from the murine LPL promoter for previously identified transcription factors OCT-1 and NF-Y were then used in EMSA competition assays against the 103and $120-\mathrm{bp}$ probes to determine their possible involvement in the TNF $\alpha$-mediated decrease in LPL transcription. Unlabeled OCT-1 consensus sequence oligos successfully competed away one of the 103-bp probe bands (Fig. $6 \mathrm{~A}$ ), whereas neither unlabeled NF-Y nor unlabeled NFkB consensus sequences were able to compete this band off. Likewise, unlabeled NF-Y consensus oligos successfully competed away one of the 120-bp probe bands, whereas OCT-1 and NFkB oligos did not (Fig. $6 \mathrm{~B})$.

To characterize further the protein-LPL DNA interactions, nuclear extracts were prepared at 1, 2, and $4 \mathrm{~h}$ after TNF $\alpha$ treatment. Using the murine LPL octamer consensus sequence, there was no loss of protein interaction at 1,2 , or $4 \mathrm{~h}$, as was seen at $18 \mathrm{~h}$, suggesting that the effect of TNF $\alpha$ on LPL promoter-binding proteins is not immediate (Fig. 7). To investigate the possibility that TNF $\alpha$ was down-regulating transcrip-

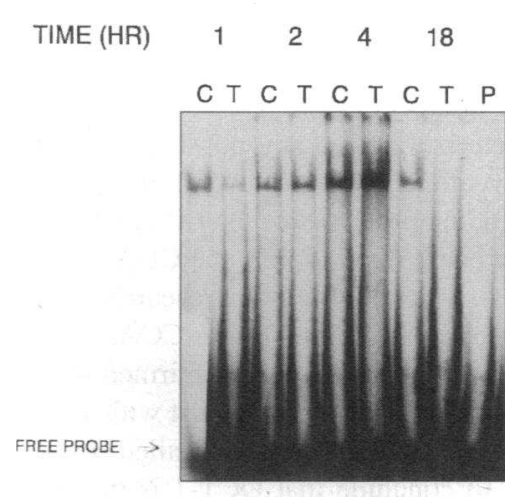

Figure 7. Time course for TNF $\alpha$ effect on protein interaction with the murine LPL octamer consensus sequence. $\mathrm{Nu}-$ clear extracts were prepared from differentiated 3T3-L1 cells with $(T)$ or without $(C) 10 \mathrm{ng} / \mathrm{ml}$ TNF $\alpha$ treatment at 1,2 , 4 , and $18 \mathrm{~h}$ and incubated with a radiolabeled double-stranded octamer consensus sequence DNA probe.

tion factors transcriptionally, the mRNA for OCT-1 was examined by RT-PCR using primers that were designed to amplify a region of mRNA shared by all three OCT-1 isoforms. There were no differences in the amount of mRNA when differentiated 3T3-L1 cells were treated with TNF $\alpha$ for $18 \mathrm{~h}$ (data not shown).

Antibodies to NF-Y and OCT-1 were then used to identify further the proteins involved in the TNF $\alpha$ effect. The antibody to NF-Y successfully supershifted the protein-NF-Y oligo complex, confirming the interaction of NF-Y with the murine LPL CCAAT box-containing oligo (Fig. 8). However, the commercially available anti-OCT-1 antibody was not able to supershift the octamer complex, although it was able to supershift the octamer complex in HeLa cells. Interestingly, by Western analysis, this anti-OCT-1 antibody detected a major band of the appropriate molecular weight (data not shown) in the differentiated 3T3-L1 nuclear extracts, suggesting that the antibody can react with some murine octamer-binding protein. Additionally, the Western analysis showed no difference with TNF $\alpha$ treatment, confirming the mRNA data that the OCT-1 protein was not down-regulated.

\section{Discussion}

These results indicate that TNF $\alpha$ affects the LPL promoter in a region that is critical for transcriptional activation. After transfection of differentiated 3T3-L1 adipocytes with variable lengths of the LPL promoter-luciferase gene constructs, TNF inhibition of LPL gene transcription appears to be mediated through a region in the proximal (180-bp) promoter fragment. This section of the LPL proximal promoter includes the CCAAT box, OCT-1 consensus sequence, and TATA box. Although the OCT-1 and TATA sites are necessary for the majority of basal

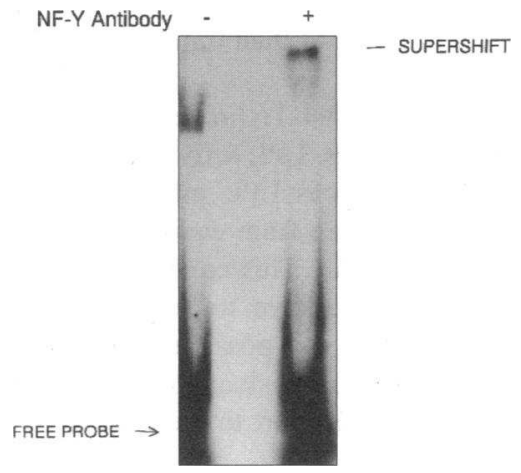

Figure 8. EMSA. The anti-NF-Y antibody was added after the binding reaction between the radiolabeled NF-Y DNA probe and the nuclear extract and incubated for 20 $\min$ at $30^{\circ} \mathrm{C}$. The antibody incubated with probe alone failed to produce a shift. 
LPL promoter activity, the CCAAT site further increases LPL promoter activity by two- to fourfold (13). Notably, the murine and human proximal LPL promoter region containing the OCT1 and NF-Y sites are 97\% identical (13).

EMSA, used to characterize further any possible proteinLPL DNA interactions, revealed the loss of several interactions between LPL promoter-binding proteins and the LPL promoter. Two of these proteins have been found to bind the CCAAT box and the octamer consensus sequence. Previous research in our laboratory identified the protein that binds to the CCAAT box of the LPL promoter as NF-Y (18). This was confirmed in our supershifts, which showed that NF-Y binding is lost with TNF $\alpha$ treatment. Because the anti-OCT-1 antibody failed to supershift, it is not possible to conclude that OCT-1 is the transcription factor binding to the octamer consensus sequence. The antibody is against human OCT-1, and although it is expected to cross-react with murine OCT-1, the affinity for murine OCT1 could be much less. Alternatively, the octamer-binding protein could be one of the recently identified splice variants of OCT1 (19) that the antibody fails to recognize.

The remaining gel shift bands have not been identified as specific protein-DNA interactions. The only other known consensus sequence in these probes is a nontraditional TRE at +28 bp (15) and two fat-specific element motifs at -80 and -143 bp (13). The fat-specific element motifs are thought to be key consensus sequences in conferring adipose-specific gene expression (20). Although TNF $\alpha$ has been shown to alter c-fos and c-jun expression in 3T3-L1 cells, and antisense c-fos has been shown to decrease LPL mRNA (21), a broadly reactive anti-c-fos antibody failed to shift any of the unidentified bands in either the 103- or the 120-bp probe (data not shown). Previous in vitro footprinting (13) using the murine LPL proximal promoter did not reveal any other protein-LPL DNA interactions, suggesting that the remaining gel shift bands may be artifacts of this technique.

The loss of multiple protein-DNA interactions suggests that TNF $\alpha$ does not work through a distinct "response element" of its own on the LPL gene, such as those that have been found for other genes, including the MHC class I or osteocalcin genes $(17,22)$. Instead, TNF $\alpha$ may work through second messenger systems to regulate several transcription factors and related cellular events.

The fact that the protein-LPL promoter interaction is sustained for over $4 \mathrm{~h}$ of TNF $\alpha$ treatment suggests that the mechanism of TNF $\alpha$ action on transcription is not immediate. Although there appears to be a transient effect on OCT-1 binding at $1 \mathrm{~h}$ with TNF $\alpha$ treatment, this was not consistently noted between nuclear extracts. OCT-1 has been shown to be phosphorylated through the actions of protein kinase $\mathrm{A}$, and this phosphorylation correlates with an inhibition of OCT-1 binding to DNA (23). The OCT-1 mRNA results support the notion that the OCT-1 protein is modified rather than transcriptionally regulated to decrease DNA binding.

Additionally, our results suggest that TNF $\alpha$ regulates LPL through posttranscriptional mechanisms. LPL activity decreases quickly and more extensively than does LPL mRNA. TNF $\alpha$ has been shown to promote LPL release from endothelial cells through phospholipase $A_{2}$ activity (24). This could also occur in adipocytes. TNF $\alpha$ has also been shown to interfere with glucose transporter translocation (25). It is possible that a similar mechanism could also prevent LPL translocation to the cell membrane for release and ultimate transport to the endothelial cell in vivo.
Lastly, the transfection analysis results that TNF $\alpha$ had a similar effect on the LPL promoter whether the murine or the human form was used indicates that the effect of TNF $\alpha$ on LPL gene transcription is mediated through the 55-kD TNF $\alpha$ receptor. Human TNF $\alpha$ has been shown to bind the $55-\mathrm{kD}$ receptor but not the 75-kD receptor in murine systems (26).

Hence, we conclude that in adipocytes, TNF $\alpha$ works both transcriptionally and posttranscriptionally to decrease LPL activity. To accomplish transcriptional regulation, TNF $\alpha$ decreases the binding affinity of at least two DNA-binding proteins, NF-Y and an octamer-binding protein, in the proximal promoter of the LPL gene, contributing to the inhibition of LPL gene expression. Furthermore, TNF $\alpha$ may work at a step that coordinately decreases the binding affinity of several DNAbinding proteins, decreasing LPL gene transcription and ultimately leading to delipidation of mature adipocytes.

\section{Acknowledgments}

The authors are grateful to Dr. J. M. Gimble for his generous gift of the LPL deletion plasmids and to C. Benoist and D. Mathis (Institut de Chimie Biologique, France) for kindly providing the NF-Y antibody. In addition, we thank K. Sundquist and D. Jensen for their helpful discussions and advice.

This work was supported by USDA National Research Initiative Competitive Grants Program award 92-37200-7522. The University of Colorado Cancer Center Center Core Laboratories are supported by National Institutes of Health award P30 CA46934.

\section{References}

1. Hotamisligil, G. S., N. S. Shargill, and B. M. Spiegelman. 1993. Adipose expression of tumor necrosis factor- $\alpha$ : direct role in obesity-linked insulin resistance. Science (Wash. DC). 259:87-91.

2. Beutler, B. A., I. W. Milsark, and A. Cerami. 1985. Cachectin/tumor necrosis factor: production, distribution, and metabolic fate in vivo. J. Immunol. 135:3972-3977.

3. Zechner, R., T. C. Newman, B. Sherry, A. Cerami, and J. Breslow. 1988. Recombinant human cachectin/tumor necrosis factor but not interleukin- $1 \alpha$ downregulates lipoprotein lipase gene expression at the transcriptional level in mouse 3T3-L1 adipocytes. Mol. Cell. Biol. 8:2394-2401.

4. Lahdevirta, J., C. P. J. Maury, A. Teppo, and H. Repo. 1988. Elevated levels of circulating cachectin/tumor necrosis factor in patients with acquired immunodeficiency syndrome. Am. J. Med. 85:289-291.

5. Moldawer, L. L., B. Sherry, S. F. Lowry, and A. Cerami. 1989. Endogenous cachectin/tumor necrosis factor-alpha production contributes to experimental cancer-associated cachexia. Cancer Surv. 8:853-859.

6. Lanza-Jacoby, S., S. C. Lansey, E. E. Miller, and M. P. Cleary. 1984. Sequential changes in the activities of lipoprotein lipase and lipogenic enzymes during tumor growth in rats. Cancer Res. 44:5062-5067.

7. Sadur, C. N., T. J. Yost, and R. H. Eckel. 1984. Fat feeding decreases insulin responsiveness of adipose tissue lipoprotein lipase. Metab. Clin. Exp. 33:1043-1047.

8. Student, A. K., R. Y. Hsu, and M. D. Lane. 1980. Induction of fatty acid synthetase synthesis in differentiating 3T3-L1 preadipocytes. J. Biol. Chem. 255:4745-4750.

9. Maniatis, T., E. F. Fritsch, and J. Sambrook. 1982. Molecular Cloning: A Laboratory Manual. Cold Spring Harbor Laboratory, Cold Spring Harbor, NY. 202 pp.

10. Chomczynski, P., and N. Sacchi. 1987. Single-step method of RNA isolation by acid guanidinium thiocyanate-phenol-chloroform extraction. Anal. Biochem. 162:156-159.

11. Eckel, R. H., P. A. Kern, C. N. Sadur, and T. J. Yost. 1986. Methods for studying lipoprotein lipase in human adipose tissue. In Methods in Diabetes Research. Vol. II: Clinical Methods. W. L. Clarke, J. Larner, and S. L. Pohl, editors. John Wiley \& Sons, New York. 259-273.

12. Dignam, J. D., R. M. Lebowitz, and R. G. Roeder. 1983. Accurate transcription initiation by RNA polymerase II in a soluble extract from isolated mammalian nuclei. Nucleic Acids Res. 11:1475-1489.

13. Hua, X., S. Enerbäck, J. Hudson, K. Youkhana, and J. M. Gimble. 1991. 
Cloning and characterization of the promoter of the murine lipoprotein lipaseencoding gene: structural and functional analysis. Gene. 107:247-258.

14. Cornelius, P., S. Enerback, G. Bjursell, T. Olivecrona, and P. H. Pekala. 1988. Regulation of lipoprotein lipase mRNA content in 3T3-L1 cells by tumor necrosis factor. Biochem. J. 249:765-769.

15. Flink, I. L., and E. Morkin. 1990. Interaction of thyroid hormone receptors with strong and weak cis-acting elements in the human $\alpha$-myosin heavy chain gene promoter. J. Biol. Chem. 265:11233-11237.

16. Yamada, H., S. Iwase, M. Mohri, and D. Kufe. 1991. Involvement of a nuclear factor-kappa-B-like protein in induction of the macrophage colonystimulating factor gene by tumor necrosis factor. Blood. 15:1988-1995.

17. Israel, A., O. La Bail, D. Hatat, J. Piette, M. Kieran, F. Logeat, D. Wallach, M. Fellous, and P. Kourilsky. 1989. TNF stimulates expression of mouse MHC class I genes by inducing an NFkB-like enhancer binding activity which displaces constitutive factors. EMBO (Eur. Mol. Biol. Org.) J. 8:3793-3800.

18. Currie, R. A., and R. H. Eckel. 1992. Characterization of a high affinity octamer transcription factor binding site in the human lipoprotein lipase promoter. Arch. Biochem. Biophys. 298:630-639.

19. Suzuki, N., P. Werner, T. Ciesiolka, P. Gruss, and H. R. Scholer. 1993. Mouse Oct-1 contains a composite homeodomain of human Oct-1 and Oct-2. Nucleic Acids Res. 21:245-252.
20. Distel, R. J., H. Ro, B. S. Rosen, D. L. Groves, and B. M. Spiegelman. 1987. Nucleoprotein complexes that regulate gene expression in adipocyte differentiation: direct participation of c-fos. Cell. 49:835-844.

21. Barcellini-Couget, S., A. Pradines-Figueres, P. Roux, C. Dani, and G. Ailhaud. 1993. The regulation by growth hormone of lipoprotein lipase gene expression is mediated by c-fos protooncogene. Endocrinology. 132:53-60.

22. Li, Y., and P. Stashenko. 1993. Characterization of a tumor necrosis factorresponsive element which down-regulates the human osteocalcin gene. Mol. Cell. Biol. 13:3714-3721.

23. Segil, N., S. B. Roberts, and N. Heintz. 1991. Mitotic phosphorylation of the Oct-1 homeodomain and regulation of Oct-1 DNA binding activity. Science (Wash. DC). 256:1814-1816.

24. Saxena, U., L. D. Witte, and I. J. Goldberg. 1990. Tumor necrosis factor induced release of endothelial cell lipoprotein lipase. Arteriosclerosis. 10:470476.

25. Stephens, J. M., and P. H. Pekala. 1992. Transcriptional repression of the C/EBP- $\alpha$ and GLUT4 genes in 3T3-L1 adipocytes by tumor necrosis factor- $\alpha$. J. Biol. Chem. 267:13580-13584.

26. Lewis, M., L. A. Tartaglia, A. Lee, G. L. Bennett, G. C. Rice, G. H. W. Wong, E. Y. Chen, and D. V. Goeddel. 1991. Cloning and expression of cDNAs for two distinct murine tumor necrosis factor receptors demonstrate one receptor is species specific. Proc. Natl. Acad. Sci. USA. 88:2830-2834. 